\title{
The exceptional preventive agreement: legal solution for companies in crisis due to the covid-19 pandemic?
}

\author{
Lissangee Stefanía Mendoza García ${ }^{1}$ \\ RubéN MÉNdez ReÁteGul2*
}

\begin{abstract}
In Ecuador has been enacted the Humanitarian Support Law to face the crisis generated by the covid-19 pandemic. This law establishes an exceptional preventive agreement with procedures to combat the crisis that the commercial sector is going through. However, a series of questions arise that motivated the preparation of this contribution. Among these questions, are these procedures -really-implemented as the right solutions to business crises? Furthermore, can effective alternatives be considered for the permanence of the companies in the market? Therefore, based on multidisciplinary methodological considerations, finding a valid and timely response has made it essential to carry out a technical-normative analysis of the exceptional pre-bankruptcy and bankruptcy scenarios that this law establishes as we propose here.
\end{abstract}

Keywords: company, economic recession, profitability, debt, bilateral agreement.

1 Legal researcher working for Ecuadorian Institute of Law and Economics Research (EILE).

2 Full professor at Pontificia Universidad Católica del Ecuador (PUCE), Facultad de Jurisprudencia and Profesor visitante de la Facultad de Derecho y Ciencias Humanas de la Universidad Tecnológica del Perú (UTP). This contribution refers to Proyecto Sistemas Legales, Eficiencia y Justicia. Participant at Programa de Posdoctorado América Latina en el Orden Global del Colegio de América Sede Latinoamericana-Universidad Andina Simón Bolívar, Sede Ecuador. Visiting researcher at Universidad Externado de Colombia and at Universidad de Salamanca (España). Doctor (Ph.D.) in Economics from Macquarie Universitty (Australia) and the UCM (España). Doctor (Ph.D.) in CCSS from Universidad Rey Juan Carlos de España. Ph.D. (c) from Universidad de Salamanca (España). Email address: rcmendez@puce.edu.ec. Orcid ID: 0000-0001-8702-5021. Scopus ID: 57192979313.

* DOI: https://doi.org/10.18601/01236458.n55.05 


\section{EL CONCORDATO PREVENTIVO EXCEPCIONAL: ¿SOLUCIÓN JURÍDICA PARA EMPRESAS EN CRISIS DEBIDO A LA PANDEMIA COVID-19?}

\section{RESUMEN}

En Ecuador se ha promulgado la Ley de Apoyo Humanitario con el fin de combatir la crisis generada por la pandemia covid-19. En dicha ley se establece un concordato preventivo excepcional con procedimientos para combatir la crisis por la que el sector comercial está atravesando. Sin embargo, surgen una serie de interrogantes que motivaron la elaboración de este aporte. Entre estas interrogantes destacan: ¿estos procedimientos - realmente- se implementan como verdaderas soluciones a las crisis empresariales? Y ¿pueden considerarse alternativas eficaces para la permanencia de las empresas en el mercado? Por tanto, a partir de consideraciones metodologías multidisciplinares, hallar una respuesta válida y oportuna ha hecho imprescindible realizar un análisis técnico-normativo de los escenarios preconcursales y concursales excepcionales que esta ley establece tal como aquí proponemos.

Palabras clave: empresa, recesión económica, rentabilidad, deuda, acuerdo bilateral.

\section{INTRODUCTION}

The appearance of the covid-19 pandemic in the world has produced unparalleled health and economic consequences. States affected by the almost uncontrollable spread, to slow the spread of the coronavirus, took emerging decisions to safeguard community health, which over time focused not only on the worrying rates of mortality from contracting the virus or the severity of its symptoms but also on the financial crisis as a result of the commercial standstill due to population confinement.

Due to the brutal blow, Ecuador, which was barely making up for its economic weakness, suffered one of the most significant recessions at the regional level after Venezuela (Álvaro, 2020), which led to a series of economic measures by the Executive Branch, such as subsidizing gasoline, reducing salaries, and reducing public entities, among others. One of them was a Bill sent to the National Assembly as a "lifesaver" to mitigate the health, economic and social crisis.

The Organic Law on Humanitarian Support to combat the health crisis arising from covid-19, from now on referred to as the "Humanitarian Law", approved by the Asamblea Nacional (it can be translated as National Assembly) and published in the Registro Oficial (it can be translated as Official Register) on June 22 2020, deals with solidarity and welfare measures, measures to guarantee the rights of workers and members of the IESS, a temporary regime to prevent bankruptcy proceedings and to encourage fair and satisfactory agreements between debtors and creditors (Cevallos, 2020). 
In the national economic sector, we can find companies, which were severely affected by the consequences of the covid-19, both health and financial, since they adapted to practical means of work, to the adaptation of biosecurity measures in their facilities and, if necessary, in the products they offer. However, more than anything else, to the economic crisis that can lower the company's profitability, and, for this, they have a business rescue measure in the Humanitarian Law, the pre-bankruptcy agreement and the exceptional procedure of preventive bankruptcy.

Therefore, this article aims to analyze two new legal institutions implemented since the publication of the Humanitarian Law, which is the pre-bankruptcy agreement and the exceptional procedure of the preventive bankruptcy, for having preliminary insights about its effectiveness and point out some reflections from the economic analysis of the Law.

\section{ECONOMIC IMPACT ON BUSINESS?}

The severity of the economic crisis in Ecuador due to the economic paralysis caused by the covid-19 pandemic is undeniable, since, according to the data from the National Accounts published in the Banco Central del Ecuador (2020) (it can be translated as Central Bank of Ecuador), "the first quarter of 2020 the Ecuadorian economy experienced a decrease of 2.4 per cent compared to the same period in 2019".

Due to this, the business sector is severely affected. We understand companies as those agents that effectively organize economic factors to produce goods and services for the market to achieve specific purposes. These ends must be achieved with efficient market strategies, thus reducing the use of resources and with good corporate governance.

Besides, we must take into account the division of companies based on the size in the following graphic:

\section{GRAPHIC 1. RANKING OF COMPANIES BASED ON SIZE}

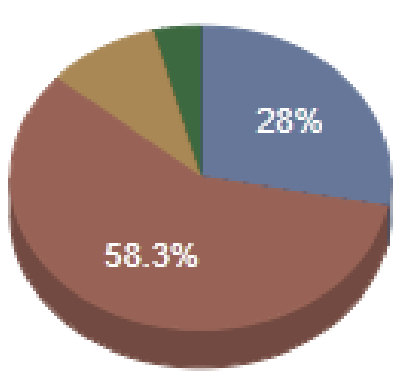

- PEQUEÑA MICROEMPR. MedianA - gRANDE

Source: Superintendencia de Compañías, Valores y Seguros (2020) (it can be translated as Superintendence of Companies, Securities and Insurance) based on information provided for the fiscal year 2019 of companies' subject to the control of the same institution. 
This division, according to Ron Amores (2017), is based on the classification of companies according to their size in which income prevails over workers, as defined by the Reglamento a la Estructura e Institucionalidad de Desarrollo Productivo de la Inversión y de los Mecanismos e Instrumentos de Fomento Productivo ${ }^{3}$ (established by the Código Orgánico de la Producción, Comercio e Inversiones $\mathrm{COPCI}^{4}$ in 2011).

1.- Microenterprises: Between 1 to 9 workers or income less than $\$ 100,000.00$

2.- Small business: Between 10 to 49 workers or Income between $\$ 100,001.00$ and $\$ 1^{\prime} 000,000.00$

3.- Medium business: Between 50 to 199 workers or Income between $\$ 1^{\prime} 000.001,00$ and $\$ 5^{\prime} 000.000,00$

4.- Large company: More than 200 workers or Income over $\$ 5^{\prime} 000.001,00$

Always predominating the Income over the number of workers (Superintendent of Companies, Securities and Insurance, 2020, s. p.)

However, it is undeniable the economic havoc that exists in all Ecuadorian companies of any size due to covid-19 (Gurrea Martínez, 2020, cited by Ortiz Mena and Noboa Velasco, 2020, p. 39), so the Cámara de Industrias y Producción evaluated possible scenarios on the possible loss of more than 69000 Ecuadorian companies (Pesantes, 2020).

Considering the financial instability of companies seriously affected by the pandemic, we must point out the importance of focusing on the viability and stability of the company in the market, through a business continuity analysis, the possible mitigation of the risk of interruption of economic activity, the possibility of relying on an agent that allows for the evaluation of the administrative and financial condition at this time, fiscal and tax obligations, also, the obligations contracted with the so-called stakebolders ${ }^{5}$.

Therefore, to determine whether the company can remain in the market or, on the other hand, to exit it in an orderly manner, the Ecuadorian State has considered implementing new rules of the game due to the health crisis by covid-19 for a due equity restructuring of the companies. Furthermore, in the case that this is not possible,

3 It can be translated as Regulation to the Structure and Institutionality of Productive Development of Investment and Mechanisms and Instruments of Productive Promotion.

4 It can be translated as Organic Code of Production, Trade and Investment.

5 The stakeholders, taking into account that they are "all persons or groups that can influence the well-being of the company, not only creditors but all those who have a direct or even indirect relationship with the company" (Mendoza García y Méndez Reátegui, 2020, pp. 372-373). 
a legal tool for the compliance of claims in an efficient way for a prompt dissolution, liquidation and cancellation of the company.

\section{LEGAL ALTERNATIVES IN HUMANITARIAN LAW}

The constant search for alternatives for adapting to and overcoming society's problems is a human need (Cabrera, 2003), and the law makes it possible to establish legislation with those alternatives to such conflicts through robust and - when is possibleformal institutions.

Patrick Barrera (2020) (quoted by Cámara de Industrias y Producción, 2020a) points out that:

Ecuador is not ready to face this crisis. The 1999 crisis was a $6 \%$ drop in GDP. The price of oil was at 7 dollars, a crisis in the foreign debt. Now we have no funds. We have an exchange regime that has no flexibility, without a bankruptcy law that allows us to restructure or reactivate companies. (s. p.)

In the same vein, Andrés Rodríguez (2020) (quoted by Cámara de Industrias y Producción, 2020b) maintains that:

It depends on the level of analysis and studies to establish an optimal and fast route of reactivation for the companies. It is necessary to understand the dynamics of each sector and where they work to provide scenarios. There will be uncertainty if the information is not gathered from the competition, and it will be difficult for us to get ahead. (s. p.)

However, the Ley Humanitaria (it can be translated as Humanity Law) (2020) has established institutions that can provide optimal solutions for a legal and financial reengineering of the companies, complying with those debts that affect the commercial viability of the company, institutions that propose to mitigate the economic impact and recover the business, as the option of a pre-bankruptcy agreement and, if this is not possible to obtain, an exceptional procedure of preventive bankruptcy.

It is worth mentioning that in Ecuador the Bankruptcy Law is in force, however, due to "a series of anachronisms and incompatibilities with reality, it has not been successfully applied nor has it helped to develop the bankruptcy processes in the country, so necessary in times of crisis" (Ortiz Mena and Noboa Velasco, 2020, p. 40).

On the other hand, the Ley Orgánica de Emprendimiento e Innovación (it can be translated as Organic Law on Entrepreneurship and Innovation) (2020) is currently in force, which determines a "restructuring of enterprises" for the microenterprise sector (formal entrepreneurship) defined in the same law. However, despite this, the exceptional preventive agreement includes characteristics that were appropriate to the national reality. 


\section{Exceptional Preventive Agreement}

The exceptional preventive agreement is established in Article 26 of the Humanitarian Law (2020), which delimits the objective and the subjects that can apply these procedures. As an objective, as mentioned above, it is "to face the economic consequences derived from the crisis caused by the covid-19", which could be used by those companies defined by the Ley de Régime Tributario Interno (it can be translated as Internal Tax Regime Law) (2004) which, although it defines it as a legal entity, with certain exceptions opens a full possibility when considering the de facto company, the mercantile trust, the holding companies, the investment fund and entities that even though they do not have legal status constitute a limited liability of their members or are an economic unit (Article 98).

It should be pointed out that this exceptional procedure is also aimed at natural persons engaged in commercial, economic, cultural and recreational activities ( $\mathrm{Hu}$ manitary Law, 2020, art. 26), however, for this article, we shall refer to the specific case of commercial companies under the control of the Superintendency of Companies, Securities and Insurance.

\section{Pre-bankruptcy exemption agreements}

These agreements established in the Humanitarian Law, are a way to avoid the bureaucratic burden of institutions that in the Ley de Concurso Preventivo y Ley de Compañías (it can be translated as Law of Preventive Contest and the Law of Enterprises, respectively) have the faculties to receive the requests of the preventive contest, for that reason, it seems to be a friendly way that the debtors (commercial companies in their different types) promote the dialogue with their creditors going to Mediation Centers guaranteed by the Council of the Judiciary.

Besides, this pre-bankruptcy agreement may exceptionally establish conditions, deadlines and the reduction, capitalization or restructuring of outstanding obligations of any kind (Humanitarian Law, 2020, art. 27), that is to say, they will have all the possibilities to reach a mutual agreement that benefits both parties since the debtor company will have the possibility to agree its outstanding obligations to remain in the market and its creditors or stakeholders will be able to satisfy their right to credit by demanding compliance with the obligation or payment of the debt.

Article 28 of the Humanitarian Law (2020), indicates how the process should be carried out within three years of the publication of the law: 
GRAPHIC 2. OF THE PROCEDURE OF THE EXCEPTIONAL PRE-BANKRUPTCY AGREEMENT

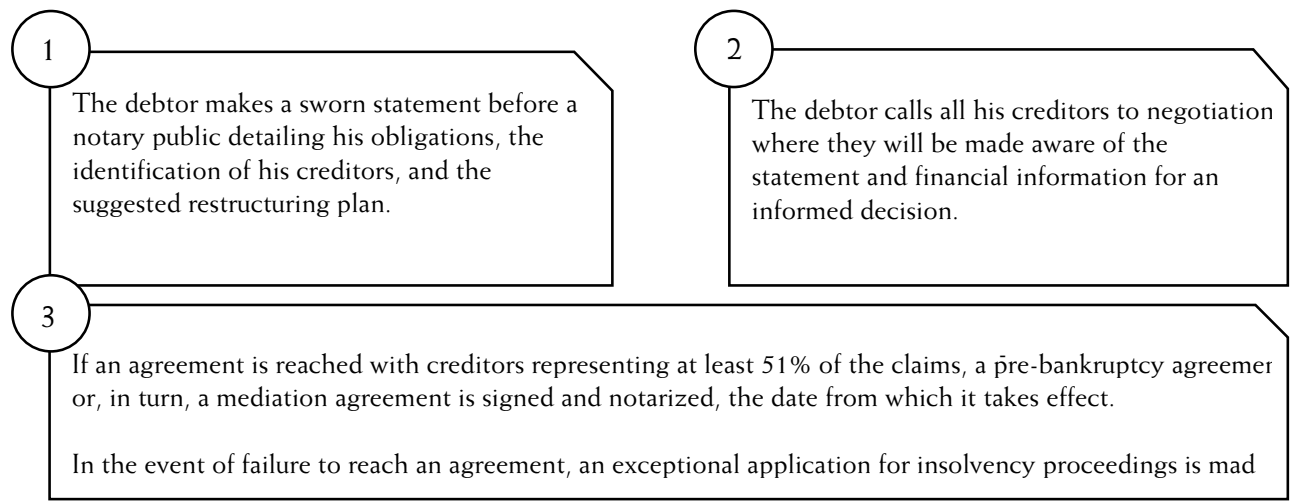

Source: Ley de Apoyo Humanitario para Combatir la Crisis Sanitaria Derivada del Covid-19 (it can be translated as Law on Humanitarian Support to Combat the Covid-19 Health Crisis) (2020) Own elaboration.

It is essential to mention that pre-bankruptcy agreement may be challenged by ordinary means and in cases where any type of damage has been caused to one or more creditors (Humanitarian Law, 2020, art. 28), since these agreements will have the force of a judgement and will be enforceable against third parties and, as established in art. 2362 of the ecuadorian Código Civil (it can be translated as Civil Code) (2005): "The transaction has the effect of res judicata in the last instance; however, a declaration of nullity or rescission may be requested".

\section{Exceptional preventive assistance}

The Humanitarian Law (2020) provides for this exceptional procedure as an option if the pre-bankruptcy agreement cannot be reached, using an unusual judicial request for preventive bankruptcy submitted by the debtor, accompanied by the act of impossibility of mediation and a sworn statement before a notary public, stating that he cannot comply with his obligations or that the debtor will not be able to comply regularly and punctually with his obligations, in addition to the specifications set out in Article 30. (Art. 30).

Once the application has been submitted with the other documents, the judge will determine whether or not are met all the legal requirements and the grounds established. If they are, through order within up to 120 days, he will order the suspension of all proceedings against the debtor and the due prohibition of the initiation of any action against the debtor. Besides, the judge will send to summon the creditors with the notice of meeting dated not earlier than five days and not later than fifteen days from the date of the notice (Humanitarian Law, 2020, art. 30). This procedure includes specific characteristics of the preventive meeting established in Código 
Orgánico General de Procesos COGEP 6 (it can be translated as General Organic Code of Processes) and in Ley de Concurso Preventivo.

As for the development of the meeting of creditors will take place on the day set for the hearing, will begin with the reading of the report of the debtor, from which the judge will open the discussion, likewise, the judge must refer the file to the prosecutor if it determines that the debtor has used the procedure to defraud their creditors and declare invalid everything acted until that time (Humanitarian Law, 2020, art. 31).

However, we must take into account that in this instance, the judge would have the figure of a conciliator who is considered an alternative method of conflict resolution. However, there is Article 32 referring to the supplementary laws in case some aspect of the procedure has not been manifested. These rules are in Código Orgánico General de Procesos COGEP and in Ley de Concurso Preventivo.

In that framework, we must mention that if the debtor's assets can comply with the payment of at least $60 \%$ of the total credits, the court will have to order a payment plan for the rest and the debtor can be rehabilitated immediately. This procedure as such is called in the Humanitarian Law "exceptional judicial rehabilitation procedure" (Humanitarian Law, 2020, art. 33).

Concerning the above, we can deduce that this exceptional reorganization proceeding can fit in with the COGEP that determines a judicial proceeding. However, there is a certain inconsistency with the Bankruptcy Law, since, in said law, when it is addressed to companies, it is a procedure separate from the judicial sphere, and it focuses more on an administrative proceeding in Superintendencia de Compañías, Valores y Seguros. Therefore, there could be the incompatibility of rules between the reorganization proceeding of the Bankruptcy Law and the exceptional proceeding determined in the Humanitarian Law.

\section{IN CONCLUSION: IS IT CONSIDERED A LEGAL SOLUTION OR NOT?}

As we have pointed out, companies are severely affected by the health, economic and social crisis caused by the covid-19 pandemic, and the forced liquidation of businesses due to the lack of profitability was inevitable, but the legal measures that have been implemented since the Law of Humanitarian Support to Combat the Health Crisis Derived from covid-19 came into force, can implement alternative ways to consider the viability of the company and remain in the market.

Within the exceptional preventive agreement, the exceptional pre-bankruptcy agreement is established. The debtor may resort to mediation as an alternative friendly

6 It is worth mentioning that the preventive contest established in the General Organic Code of Processes refers only to commercial or non-commercial debtors except companies subject to the control of the Superintendence of Companies, Securities and Insurance or the Superintendence of Banks, which will be subject to the particular law, which in this case is the Preventive Contest Law (COGEP, 2015, art. 415-427). 
method with the incentive of a restructuring plan and compliance with outstanding obligations to creditors, which we consider to be an effective and quick way to achieve mutual benefit and to keep the company in the business. Also, the act of mediation containing the pre-bankruptcy agreements has the effect of the last resort judgment and of res judicata, which provides legal certainty for both parties, and also if these agreements can be challenged due to the detriment of one or more creditors.

Suppose the creditors disagree and mediation is not possible. In that case, there is another alternative which would be to request the exceptional reorganization proceeding. However, in this procedure, there are certain inconsistencies such as the case of debtor companies which should be governed as a supplementary law to the reorganization law. Then it does not indicate a judicial but an administrative venue, neither the possibility of a judge as a conciliator of a meeting between the debtor and its creditors and neither the transaction costs that would be involved in going to a judge, among others.

Therefore, we consider that these procedures have advantages and disadvantages. However, if they would effectively promote the obtaining of agreements between the debtor company and its creditors so that, on the one hand, the viable company but affected by the crisis can remain in the market and can restructure its assets or the company that has no possibility of remaining, or leaving the market in an orderly manner and, on the other hand, its creditors can benefit from the compliance of the pending obligations to accelerate the process, either of the two possibilities of the debtor.

\section{BIBLIOGRAPHY}

Álvaro, C. (14 May 2020). El Covid-19 sitúa a Ecuador al borde del abismo económico. Capital Madrid. Retrieved from: https:/www.capitalmadrid.com/2020/5/14/56495/elcovid-19-situa-a-ecuador-al-borde-del-abismo-economico.html

Asamblea Nacional del Ecuador. (2015). Código Orgánico General de Procesos. Registro Oficial 506 of May 22, 2015.

Asamblea Nacional del Ecuador. (2020). Ley de Apoyo Humanitario para Combatir la Crisis Sanitaria Derivada del Covid-19. Registro Oficial 225 of June 16, 2020.

Banco Central del Ecuador. (2020). La economía ecuatoriana decreció 2,4\% en el primer trimestre de 2020. Retrieved from: https://www.bce.fin.ec/index.php/boletines-deprensa-archivo/item/1370-la-econom\%C3\%ADa-ecuatoriana-decreci\%C3\%B3-24-enel-primer-trimestre-de-2020

Cabrera, I. (2003). El procesamiento humano de la información: en búsqueda de una explicación. ACIMED, 11(6).

Cámara de Industrias y Producción. (2020a). Webinar: Ley de Apoyo Humanitario. https:// www.cip.org.ec/2020/06/29/webinar-ley-de-apoyo-humanitario/

Cámara de Industrias y Producción. (2020b). Reactivación y expectativas económicas. https:// www.cip.org.ec/2020/07/03/webinar-reactivacion-y-expectativas-economicas/ 
Cevallos, F. (2020). Actualización de la reforma a la Ley Humanitaria. [Webinar]. https:// www.youtube.com/watch?v=gaJysibHGVE

Congreso Nacional del Ecuador. (2005). Código Civil. Code 10. Registro Oficial 46 of June 24, 2005 .

Congreso Nacional del Ecuador. (2004). Ley Orgánica de Régimen Tributario Interno LORTI. Code 26. Registro Oficial 463 of November 17, 2004.

Mendoza García, L. y MÉndeZ ReÁTEGui, R. (2020). Algunos aspectos teóricos-conceptuales de la regulación del procedimiento concursal preventivo para compañías mercantiles en Ecuador. In R. BARCia, M. SAFar, G. Lascano y R. MÉndeZ, Reflexiones jurídicas VI (segunda parte) (pp. 357-399). Quito: Centro de Publicaciones de la Pontificia Universidad Católica del Ecuador.

Ortiz Mena, E. y Noboa Velasco, P. (2020). Propuestas societarias y concursales para mitigar el impacto económico del covid-19 en Ecuador. X-Pedientes Económicos, 4(8), pp. 38-48.

Pesantes, K. (18 April 2020). El impacto del Covid-19 en la economía tiene tres escenarios. Primicias. https://www.primicias.ec/noticias/economia/impacto-covid-19-economiaescenarios/

Portilla Ruiz, J. C. y Méndez ReÁtegui, R. (2020). Algunas consideraciones preliminares sobre el pacto entre accionistas y el -buen- gobierno corporativo. In F. BENATTI, G. LASCANO BÁEZ y R. MÉNDEZ REÁTEGUI, Jornadas Internacionales de Derecho 2020 (pp. 157 163). Quito: Centro de Publicaciones de la Pontificia Universidad Católica del Ecuador. Presidente Constitucional de la República. (2011). Reglamento a la Estructura e Institucionalidad de Desarrollo Productivo de la Inversión y de los Mecanismos e Instrumentos de Fomento Productivo, establecidos Código Orgánico de la Producción, Comercio e Inversiones COPCI. Executive Decree 757. Registro Oficial 450 of May 17, 2011.

Ron Amores, R. E. y SaCoto Castillo, V. A. (2017). Las PymES ecuatorianas: su impacto en el empleo como contribución del PIB PYMES al PIB total. Revista Espacios, 38(53). https:// www.revistaespacios.com/a17v38n53/a17v38n53p15.pdf

Superintendencia de Compañías, Valores y Seguros. (2020). Ranking Empresarial 2020. https:// appscvs.supercias.gob.ec/rankingCias/ 